\title{
LAY CARDIOLOGISTS
}

\author{
BY \\ TERENCE EAST
}

\begin{abstract}
"For so to interpose a little ease" is well enough in these times, even in a scientific journal. It is hardly fair to complete the quotation, for the " surmise" of the lay writek is often far from "false." * From time to time, in desultory reading, one's attention is arrested by a good description by a lay author of a clinical condition; those which follow are of cardiovascular interest. The description by W. N. P. Barbellion of his disseminated sclerosis in the Journal of a Disappointed Man once attracted much interest. He also gave an account of his extrasystoles.
\end{abstract}

" Bad heart attack all day. Intermittency is very refined torture to one who wants to live very badly. Your pump goes 'dot and carry one,' or say, ' misses a stitch,' what time you breathe deep, begin to shake your friend's hand, and make a farewell speech. Then it goes on again and you order another pint of beer. It is a fractious animal within the cage of my thorax, and I never know when it is going to escape and make off with my precious life between its teeth."

The alarm that these harmless disturbances occasion was also well described by Hugh Walpole in his novel The Old Ladies.

"A new sound that May had never heard in that house before. It was the dripping of a tap . . . like someone counting time-1, $2,3,4$, then a pause; then several drips together. ... May began to count-she counted to ten and after that so many came together that she could count no longer ... . she lay, the sweat on her forehead, her body trembling, her heart running and jumping and missing, and jumping and running. She heard it so plainly that it seemed that it must be with her now beside her bed, the running tap."

There are many good clinical references in Kipling's writings. The only one of cardiovascular interest is the description in The Light that Failed of what would appear to be a patient with aortic regurgitation who has just climbed a flight of stairs,

\footnotetext{
* "For so to interpose a little ease let our frail hearts dally with false surmise."-Milton's Lycidas.
}

"His lips were parted and pale, and there were deep pouches under the eyes. 'Weak heart,' said Dick to himself as he shook hands, " very weak heart. His pulse is shaking his fingers." "

Samuel Johnson diagnosed the cardiac origin of his asthma correctly. - Writing to Dr. Brocklesby, his physician, after a visit to Lichfield, he remarked, "The asthma has no abatement. Opiates stop the fit, so that I can sit and sometimes be easy, but they do not procure me the power of motion. I am looking into Floyer, who lived with his asthma to almost his ninetieth year. His book by want of order is obscure; and his asthma not of the same kind with mine." Later in the year he died of heart failure, and the autopsy showed that he had had high blood pressure. His well-known account of his stroke which he had had the year before agrees with this.

"I went to bed, and in a short time waked and sat up, as has long been my custom, when I felt a confusion and indistinctness in my head, which lasted, I suppose, about half a minute. I was alarmed, and prayed God, that however he might afflict my body, he would spare my understanding. ... . I had no pain, and so little dejection in this dreadful state, that I wondered at my own apathy, and considered that perhaps death itself, when it should come, would excite less horror than seems now to attend it.

"In order to rouse the vocal organs, I took two drams. Wine has been celebrated for the production of eloquence. I put myself into violent motion, and I think repeated it; but all was in vain. I then went to bed, and strange as it may seem, I think slept. When I saw light, it was time to contrive what I should do. Though God stopped my speech, he left me my hand; I enjoyed a mercy which was not granted to my dear friend Lawrence, who now perhaps overlooks me as I am writing, and rejoices that I have what he wanted. My first note was necessarily to my servant, who came in talking, and could not immediately comprehend why he should read what I put into his hands.

"I then wrote a card to Mr. Allen, that I might have a discreet friend at hand, to act as occasion 
should require. In penning this note, I had some difficulty; my hand, I knew not how or why, made wrong letters. I then wrote to Dr. Taylor to come to me, and bring Dr. Heberden: and I sent to Dr. Brocklesby, who is my neighbour. My physicians are very friendly, and give me great hopes; but you may imagine my situation. I have so far recovered my vocal powers, as to repeat the Lord's Prayer with no very imperfect articulation."

He made rapid recovery, and had "leave to wash the cantharides" from his head a fortnight after the stroke, which was no doubt hypertensive encephalopathy.

In Treasure Island there is a short vivid description of an apoplectic attack. "I heard a loud fall in the parlour, and running in, beheld the Captain lying full length on the floor. He was breathing very loud and hard; but his eyes were closed, and his face a horrible colour."

Whether the philosopher Seneca * really had angina pectoris is doubtful. He described an attack in these words (Epistula Morales LIX): "But I have been assigned, so to speak, to one special ailment. The attack is of very brief duration, like that of a squall at sea; it usually ends within an hour. I have passed through all the ills and dangers of the flesh; but nothing seems to me more troublesome than this. And naturally so; for any-

- thing else may be called illness, but this is a sort of continued 'last gasp.' Hence physicians call it 'practising how to die." "As he lived long after and died by his own hand ultimately, perhaps his "meditatio mortis" was really bronchial asthma. In the Swan of Litchfield by J. E. Pearson, there is an excellent account of angina of effort, which culminated in a fatal attack on stooping. Anne Seward, the heroine of the book, describes the death of her old friend Mr. Saville, which took place on August $16,1803$.

"In April he began to complain, at times, of a stricture in his breast-a slight pain there, and a difficulty in breathing on going upstairs, or uphill. A disorder so entirely new to his frame startled me, but neither of us supposed the symptoms dangerous. His appetite, his spirits good, and the malady apparently trivial and infrequent; yet alas! I am now convinced these were the presage of the disease which destroyed him." He had been dressing for a party. "Soon after he cut a corn, which pained him, and in that operation had been stooping over his stomach some time, when suddenly a tremendous seizure of the late kind attacked him, and in a quarter of an hour struck him from the land of the living."

* Translation by R. M. Gunmere (Loeb series).
The following passage from Middlemarch describes what might well have been a painless attack of myocardial infarction.

"Dorothea had not looked away from her own table when she heard the loud bang of a book on the floor, and turning quickly saw Mr. Casaubon on the library steps clinging forward as if he were in some bodily distress. She started up and bounded towards him in an instant; he was evidently in great straits for breath. Jumping on a stool she got close to his elbow and said with her whole soul melted into tender alarm:- 'Can you lean on me, dear?' $\mathrm{He}$ was still for two or three minutes which seemed endless to her-unable to speak or move, gasping for breath. When he at last descended the three steps and fell backwards into the large chair, he no longer gasped, but seemed helpless and about to faint."

His physician, Mr. Lydgate, makes his diagnosis and prognosis. "My conclusions are doubly uncertain, uncertain not only because of my fallibility, but because diseases of the heart are eminently difficult to found predictions on. I believe you are suffering from what is called fatty degeneration of the heart which was first divined and explored by Lænnec. It is my duty to tell you that death from this disease is often sudden. At the same time, no such result can be predicted. Your condition may be consistent with a tolerably comfortable life for another fifteen years or even more."

Mr. Casaubon was found dead sitting in his summer house, not long after this. The prognosis which George Eliot puts-into the mouth of the doctor is cleverly worded, and would be a model of instruction for a student.

An atypical attack of coronary occlusion seems to be the subject of one of Cowper's letters (May 1785).

"Mr. Ashburner, the elder, went to London on Tuesday sennight in perfect health and in high spirits, so as to be remarkably cheerful, and was brought home in a hearse the Friday following. Soon after his arrival in town, he complained of an acute pain in his elbow, another in his shoulder, then in both shoulders; was blooded; took his doses of such medicine as an apothecary thought might do him good, and died on Thursday morning at ten o'clock. It is not common, however, for men at the age of thirty-six to die so suddenly," he comments; in those days, too, early cases appear to have occurred, one may remark.

In Horace Walpole's letters there are many medical references, chiefly on the subject of gout. There is one which may be included here. In one he laments the death of his friend Mr. Chute, also a victim of gout, in a letter to Sir Horace Mann in Florence. 
"I was never alarmed till last summer when he had a low lingering fever and sickness, and pain in his breast with returns of the recurrent palpitation. ... O On Thursday last ... I was told he was very ill, I found him in bed; he had so violent pain in his breast that two days before he had sent for Dr. Thomas, who had given him one hundred drops of laudanum and asafœida: Mr. Chute said 'It is not gout, I have had my palpitation and fear it is something of a polypus!,"

He died suddenly. Walpole comments "It certainly was a polypus; his side grew immediately as black as ink." If this account is correct it might possibly have been a dissecting aneurysm, with rupture into the pleura.

To turn to more modern writers, there is a firstrate account of the symptoms of cardiac infarction in Time Must Stop by Aldous Huxley.

"And then suddenly the pain was like a red hot poker thro' his chest. ... He felt dizzy and a whirling blackness obscured the outside world. : . . He lowered himself unsteadily onto the seat and almost immediately felt a good deal better. . . . Just as his arm was at full stretch the pain returnedbut in a new form: for now it had become, in some indescribable way, obscene as well as agonizing. And all at once he found himself panting for breath, and in the clutch of a new terror more intense than any he had ever experienced before. Then all at once the pain shot down his left arm, nauseating, disgusting, like being hit in the wind."

Sparkenbroke by Charles Morgan provides another good description of an attack of angina brought on by cold.

" In the evening, a little before dusk, while he was washing in cold water, he received warning that a paroxysm was about to seize him. A stiffness of neck and shoulder was followed by a deep aching within the left arm, and, after a little interval, by an agony within the leg as though a wedge were being driven into the bone's marrow and the bone itself split. He had dragged himself from the washstand to his bed and covered himself, for he was half naked, his body still wet and now bitterly cold. As the pain increased, the leg stiffened; his back arched; his arm, beyond his will, was twisted under his back, and he cried out, for his ampoules of amyl nitrite were in the coat he had taken off. Bissett, hastening in, put one of these into a handkerchief and the handkerchief within the grip of his hand. He crushed it and inhaled. For a little while it gave relief. His body was loosened from its contortion and he lay against pillows, struggling for breath, asking that he might escape the greater paroxysm of the body itself.

"But the agony swept upon him afresh. There appeared in his mind an image of his chest as a bony shell within which the organs of his body were being compressed by cords. The organs themselves had individuality and voices; he heard them cry out, saw them twist and spurt, emptying their blood-red to a pearly and sweating grey. Far off, within the divisions of his fingers, were folds of linen; he raised them up; a handkerchief was twined against his nostrils, which sucked in its fumes. They had the smell of comfort, but a gust of torment swept them away, and he saw Bissett laying hot compresses on the bony shell, which heat could not penetrate. . . . He gathered his knuckles into the softness of his throat." *

The art of writing clinical descriptions is almost . lost nowadays. The dry deserts of modern medical literature would make better reading if something of the charm of these lay authors could be imparted to them!

* Some of these excerpts, with others less pertinent to cardiology have appeared in the King's College Hospital Gazette (1947), Vol. 26.

\section{EDITORIAL NOTE}

What was almost certainly a paroxysm of auricular fibrillation has been described in the literature of the 1914-18 war, when the author was almost exhausted by the hardships involved in escaping on foot from a prisoner's camp: "Owing to the mud I began to feel frightfully tired. I staggered, and quite suddenly I collapsed and lay on the ground unable to move. I managed to put my hand over my heart and could feel that it was running most irregularly and misfiring in an extraordinary way. After about a quarter of an hour it got much better, so I had a few mouthfuls of bread and went on again." (The Escaping Club, by A. J. Evans. John Lane, Lond., 1929, p. 224). The sudden collapse and the sudden recovery make it much more likely that this was paroxysmal fibrillation than a bout of frequent extrasystoles.

East has included cardiovascular disease and this allows a reference to the cardiovascular accidents that give more play to the lay writer because their results are more obvious in disorders of behaviour and mannerisms. Charles Dickens has many such 
instances and shows by these, as in other ways, his great powers of accurate observation. The mental changes and change of temperament in Mrs. Gargery in Great Expectations after a blow on the back of the head, and the detailed account of the degenerative changes following on cerebral arteriosclerosis on the Honourable Mrs. Skewton, the mother of Mrs. Dombey, are detailed and accurate and must have been based on personal observation of cases. These have been dealt with fully by Russell Brain in the London Hospital Gazette, January 1942. He is able to diagnose that Mrs. Gargery had a severe contusion of the left temperoparietal region causing jargon aphasia and word deafness and some traumatic dementia, with injury to the third or sixth cranial nerve leading to diplopia.

An equally detailed diagnosis of a hæmorrhage from a posterior inferior cerebellar artery in the case of James Armitage, alias Trevor (The Gloria Scott) could be made from the pages of Conan Doyle, but perhaps this is an unfair addition as medical authors have been excluded. Even so, readers who look for it may be surprised by the amount of accurate medical detail in the Sherlock Holmes stories. Major Sholto died from left ventricular failure, and orthopnœa is rightly emphasized as a leading symptom. "When we entered his room he was propped up with pillows and breathing heavily . . . grasping our hands he made a remarkable statement in a voice broken as much by emotion as by pain. . . . At this instant a horrible change came over his expression-his eyes stared wildly, his jaw dropped, and he yelled, 'Keep him out.' We rushed to the window and when we returned his head had dropped and his pulse ceased to beat." (The Sign of Four). No wonder his son, Thaddeus Sholto, became hypochondriacal about his mitral valve.

The other is a good description of an aortic aneurysm. When Jefferson Hope was arrested he remarked that he might not live for the trial. "It isn't suicide I am thinking of; put your hand on my chest," he said. Watson did so and at once became conscious of an extraordinary throbbing and commotion inside. The walls of his chest seemed to quiver as a frail building would when some powerful engine was at work. In the silence of the room he could hear a dull humming and buzzing noise which proceeded from the same source. Watson diagnosed an aortic aneurysm and the diagnosis was confirmed by his death from its rupture that afternoon (The Study in Scarlet).

I have dealt more fully with these medical aspects in the Guy's Hospital Gazette (Vol. 48, p. 524, 1934 and Vol. 49, p. 2 and 27, 1935).

Maurice Campbell. 